\title{
RESIDENTIAL PROPERTY PRICE INDICES ON SMALL PROPERTY MARKETS
}

\author{
Sebastian Kokot, assoc. prof., PhD \\ Faculty of Economics and Management \\ University of Szczecin \\ e-mail: sebastian.kokot@wneiz.pl
}

\begin{abstract}
There are many reasons for the fact that reliable property indices are difficult to calculate. Even though, in theory, there are several acknowledged methods of their determination, this task poses problems of various nature in practice. These problems grow when the data sets are limited, which is the case on small property markets where the number of transactions are low. The paper is an attempt to compute property price indices on the basis of a statistically smoothed series of average unit prices of residential properties sold on a small market, exemplified by the county of Łobez. Additionally, the paper discusses the problems that have emerged over the course of the study, as well as the obtained results, as viewed in the context of the general situation on the property market.
\end{abstract}

Key words: real property market, property price indices.

JEL Classification: R20.

Citation: Kokot S., 2017, Residential Property Price Indices on Small Property Markets, Real Estate Management and Valuation, vol. 25, no. 1, pp. 5-18.

DOI: $10.1515 /$ remav-2017-0001.

\section{Background}

Knowledge of price movements on the real property market is an important element of the expertise of anyone dealing with property management, i.e. for investors, appraisers, agents, managers, banks, developers, and investment funds, as well as for private individuals who are not professionally involved in this market (FRANCKE 2010). There are even opinions that the dynamics of asset prices, including real property prices, is a fundamental indicator when examining the dynamics of a given economy (GOODHART 2001). Moreover, in Poland, the obligation to use property price indices for specific purposes is stipulated by the law ${ }^{1}$. Statistical measures reflecting price movements seem to be simple to determine. Unfortunately, in practice, this is not simple at all. The problems result from the specific nature of the property market as a whole, as well as from the character of the property itself as a marketed product (e.g. see: Wycena nieruchomości 2006). A non-standard way of observing prices on the real property market makes traditional techniques of research into the dynamics of the phenomena useless (WOOD 2005) because the number of transactions is usually small and each sold property varies significantly from the others. Consequently, transactions concluded in subsequent periods of time include groups of properties differing greatly from one another in terms of their various traits. This problem is regarded as fundamental when analyzing price dynamics on property markets (GUO, ZHENG, GELTNER, LIU 2014) and it is clear that, in the case of small property markets, it will be amplified. What may be indicative of the gravity of the problem is the fact that the Polish Central Statistical Office started including property price indices in its reports no earlier than 18 years

\footnotetext{
1 Art. 33, 68, 132, 140, 148, 163 of the Act of 21 August 1997 on real estate management (i.e. Journal of Laws of the
} Republic of Poland of 2015 item 782 as amended) 
after being obliged to do so by the Real Property Management Act ${ }^{2}$. What is problematic, apart from the availability and quality of data, is their comparability, since the property market, and its residential segment in particular, is always of a local character (ŁASZEK, WIDŁAK 2008). In such a context, the development of standardized methods to examine property price dynamics on local markets appears to be an important task. Bearing the above in mind, this paper is a valuable contribution to research on methods of studying price dynamics on property markets, with a special focus on small local markets. The principal purpose of this paper is to indicate, via empirical research, the possibility to determine such indices for small property markets by means of compiling two methods of smoothing the time series of average unit residential property prices.

Methods used to determine property price indices generally fall into three categories:

1. Methods based on average unit prices in specific periods of time, where we calculate the mean or median of market prices reported over a given time and then refer it to the corresponding mean in the previous period of time, disregarding the non-homogeneity of the sample. The method is used in many variations, depending either on the way the groups of properties are segregated, or on the way in which the obtained time series of these prices are transformed. An undisputable advantage of these methods is the relative simplicity of calculations. Their disadvantage, however, is the diversified qualitative structure of the groups of marketed real property for which the average values in specific periods are calculated (BOURASSA, HOESLI, Sun 2006, JANSEN, VRIES, COOLEN, LAMAIN, BOELHOUWER, 2007).

2. Resale price methods, where price indices are computed for properties that have been sold at least twice in the period under study and next the results are averaged for a given market. A drawback of this method are the value affecting changes to the property made between the transactions. The effect is multiplied by the fact that some transactions are made with the purpose of upgrading a property and reselling it at a higher price.

3. Methods using hedonic or econometric models, where the dependent variable is the price, while the explanatory variables are the characteristics of the heterogenic good (TOMCZYK, WIDŁAK 2010). Such models are applied in examining price changes on heterogenic good markets (such as real property ones) because they account for changes in the quality of the good (WIDŁAK 2010). When this is the case, they are used for property valuation and, in the next step, indices are calculated on the basis of this valuation. The advantage of these methods is that they offer the possibility to take into account the effect that specific property attributes have on property value. On the other hand, their disadvantage is that they require collecting and constantly updating a large amount of data necessary to construct a model and valuate the property (NICHOLAS, SCHERBINA 2013). Moreover, even such indices cannot include all of the property characteristics that influence price (HILL 2011), especially given that our experience shows how difficult it is to build good or very good models of property value (the obtained $\mathrm{R}^{2}$ coefficients rarely reach 0.8 , often being much lower; see: CEGIELSKI 2013).

The above-listed methods are used in their various types or take hybrid forms (TROJANEK 2008).

\section{Area of Research and Statistical Data}

The area of research is the district (Polish: powiat) of Łobez. The district is situated in the central part of the West Pomeranian Province (Polish: województwo). It was established on 1 January, 2001 from parts of the Gryfice, Goleniów and Stargard districts, and consists of 5 communes (Polish: gmina): Dobra, Łobez, Radowo Małe, Resko and Węgorzyno. The district of Łobez is the least populated in West Pomerania, with 37,931 residents in 2014 (STAN I STRUKTURA LUDNOŚCI...), and covers an area of $1,065.13 \mathrm{~km}^{2}$ (POWIERZCHNIA I LUDNOŚć... 2014). It also has the smallest budget in the province. The number of registered unemployed has reached app. 2,800 (BEZROBOTNI ORAZ STOPA BEZROBOCIA...2014), which gives an unemployment rate of $25.8 \%$. Its small size and population, as well as weak economy, make for the local real property market being relatively narrow and poor, which is confirmed by the small number of sold properties, especially residential ones (Table 1).

The data used in the study refer to sold residential units regarded both, as objects of separate ownership and cooperative ownership rights. The transactions were identified by virtue of the transaction date and price, as well as property size, in order to compute the unit prices in individual

\footnotetext{
${ }^{2}$ Up to now, only two Notices of the President of the Central Statistical Office on price change indices for residential properties in individual voivodships in the second and third quarter of 2015.
} 
transactions. Moreover, the transactions were classified according to the location of property - each of them was included in the Whole District group and, additionally, in one of two subgroups:

- Town - when the property was located within the district capital limits,

- District Excluding Town - when the property was located outside the limits.

The data come from the Register of Prices and Values of the District Geodetic and Cartographic Documentation Center in Gryfice and from the local housing association. The data refer to the period from June 2005 to April 2015. The number of the identified transactions has been shown in Table 1.

Number of transactions identified in the course of the study

Table 1

\begin{tabular}{cccc}
\hline Year & Town of Łobez & Whole District & $\begin{array}{c}\text { District excl. town of } \\
\text { Łobez }\end{array}$ \\
\hline 2005 (from June) & 21 & 53 & 32 \\
\hline 2006 & 51 & 130 & 79 \\
\hline 2007 & 49 & 150 & 101 \\
\hline 2008 & 50 & 154 & 104 \\
\hline 2009 & 52 & 130 & 78 \\
\hline 2010 & 44 & 132 & 88 \\
\hline 2011 & 45 & 152 & 91 \\
\hline 2012 & 74 & 165 & 87 \\
\hline 2013 & 53 & 140 & 85 \\
\hline 2014 & 33 & 118 & 28 \\
\hline 2015 (up to April) & 13 & 41 & \\
\hline
\end{tabular}

Source: Own study.

\section{Research Method}

In a further part of the paper, an attempt is made to calculate the property price indices for a specific residential segment of a small local property market by means of the first of the above-mentioned methods. As had been mentioned earlier, the existing research points to considerable imperfection of average (both the arithmetic mean and the median) residential property unit prices used as the basis for determining real property price indices. It emerges that, due to a diversified qualitative structure of real properties, the average unit prices in particular periods of time demonstrate such substantial diversity that the indices calculated on their basis often have unrealistic values. Therefore, if series of average unit prices of residential properties are to be used to determine residential price indices, they require proper adjustment. Since we, the researchers, have no control over the number of transactions, the recorded transaction prices and which properties will be marketed and when, this adjustment must refer to actual facts, i.e. to the existing data about transactions occurring on the given local market. It is, therefore, a question of attributing each of the periods under study with such a unit price value that can be regarded as typical or representative for that market in a given period of time, even though it can be vitiated with a relatively small error. For the purpose of this paper, it has been assumed that the values of adequately smoothed unit price time series can prove viable. The smoothing of the average unit price time series aims to maintain the main trends in the course of the observed phenomenon, with simultaneous elimination of random oscillations resulting from the specific nature of sets of transactions on the real property market and reinforced by the fact that the area of research is a small market.

Random oscillations can be eliminated in two ways:

1. by extending the periods for which the average unit prices are determined, thus obtaining larger sets of prices that are less diversified over individual periods in terms of their quality (КОКОт 2015A). The main limitation of this method are automatically extended periods for which the indices are calculated, e.g. instead of monthly indices we obtain quarterly or semiannual ones. Consequently, the information about price movements on real property that is represented by such indices is less accurate. It is worth noting that the very procedure of smoothing property price time series by means of extending the periods of observation is effective when applied on large markets; 
2. by smoothing the time series of average unit prices with the moving average methods. However, research shows that simple moving averages poorly eliminate random price oscillations, particularly when computed from a small number of periods. What is more, even though moving averages computed from a larger number of periods (e.g. 7) perform better, they are still sensitive to incidental strong oscillations in the series of average unit prices (КОКОT, BAS 2013). An additional negative effect of smoothing the unit price series with simple moving averages is the loss of observations in the initial and final periods (HOZER et al. 2002). Unsatisfactory effects of using simple moving averages as a method of smoothing average unit prices are an impulse for further exploration and applying more complex procedures, so-called filters.

The salient characteristics of a small market make it particularly difficult to successfully smooth the time series of average prices. Therefore, in this regard, both of the methods were used simultaneously, with mechanical smoothing performed by a procedure of several passes of smoothing with various moving averages called the $4253 \mathrm{H}$ filter (VELLEMAN 1980). The filter is used not only in economics, but in many fields of science, eliminating the so-called random errors from the course of the observed phenomena. Its application usually results in very good performance of the "original" course of a phenomenon, with levelled off random oscillations and marked principal attributes of the original series (GAMRACKI, GAMRACKI 2009). In order to smooth the series with the $4253 \mathrm{H}$ filter, the following transformations need to be performed:

1. smooth the series with a 4-point moving median centered by means of a 2-point median,

2. smooth the series obtained in step (1) with the 5-point moving median,

3. smooth the series obtained in step (2) with the 3-point moving median,

4. smooth the series obtained in step (3) with the 3-point weighted moving average using Hanninh weights $(0.25,0.5,0.25)$,

5. calculate the remainders by subtracting the transformed series from the original one,

6. repeat steps 1-4 for the remainders,

7. add the transformed remainders to the transformed series.

The whole study was conducted in the following stages:

1. The monthly, quarterly, semi-annual and annual time series of the medians of unit transaction prices were constructed by calculating the medians of unit prices obtained in transactions identified in individual periods in:

- the district capital,

- the whole district (including the district capital),

- the district excluding the district capital.

2. The time series obtained in Stage I were smoothed with the use of the $4253 \mathrm{H}$ filter algorithm available in Statistica.

3. Basing on the series of medians and smoothed medians obtained in Stages I and II, the chain indices were determined with the formula:

$$
i_{t}=\frac{X_{t}}{X_{t-1}}
$$

where:

$X_{t}$ - the average unit price measure (median or smoothed median) in the period for which the index has been calculated,

$\mathrm{X}_{\mathrm{t}-1}$ - the average unit price measure (median or smoothed median) in the period preceding the period for which the index has been calculated.

The findings are shown in diagrams -line graphs for the series of medians and smoothed medians, and bar charts for the indices.

\section{Results and Discussion}

Figures 1-4 show the monthly, quarterly, semi-annual and annual medians of residential property unit prices in the district of Łobez as a whole, in the district capital and in the district excluding the district capital. We can see the ragged graphs of the monthly medians, which means that the price medians oscillate frequently and dramatically even on a short-term basis. It is highly unlikely that this variability is the effect of the real changes in market trends, i.e. the ones that are to be identified. Referring the obtained results to the number of transactions recorded in individual periods of time 
(Table 1), it is beyond any doubt that the observed variability results from random changes in the qualitative structure of residential properties marketed in a given month. It should also be recalled that, in the observed market, the monthly number of transactions rarely exceeded a dozen (the highest number of 26 transactions in the entire district was recorded in 2012). Therefore, it is not surprising that the monthly price medians are not representative of this small local market and their values are largely accidental and, as a consequence, should not be used to determine residential property price indices.

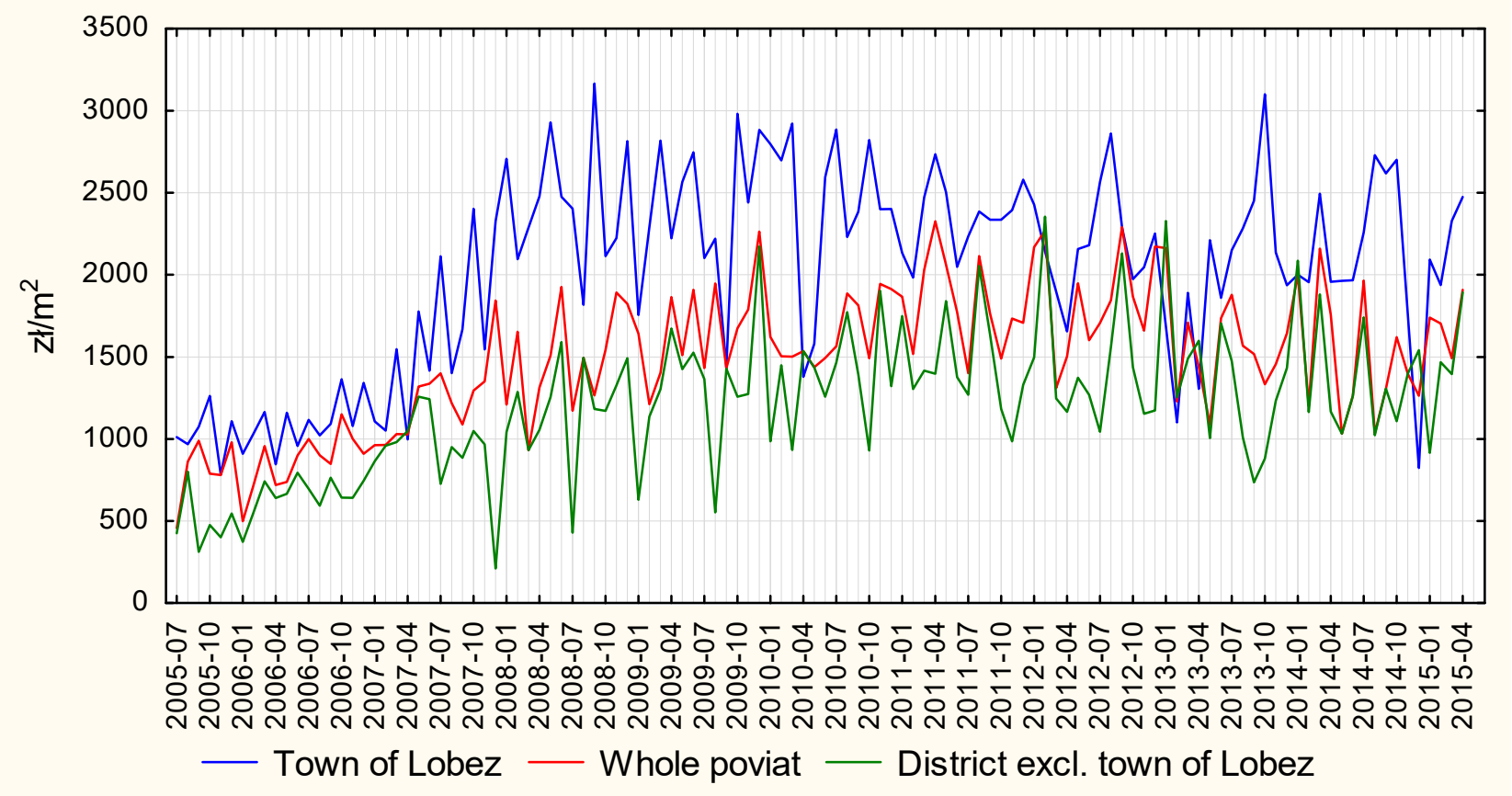

Fig. 1. Monthly medians of residential property unit prices Source: own study.

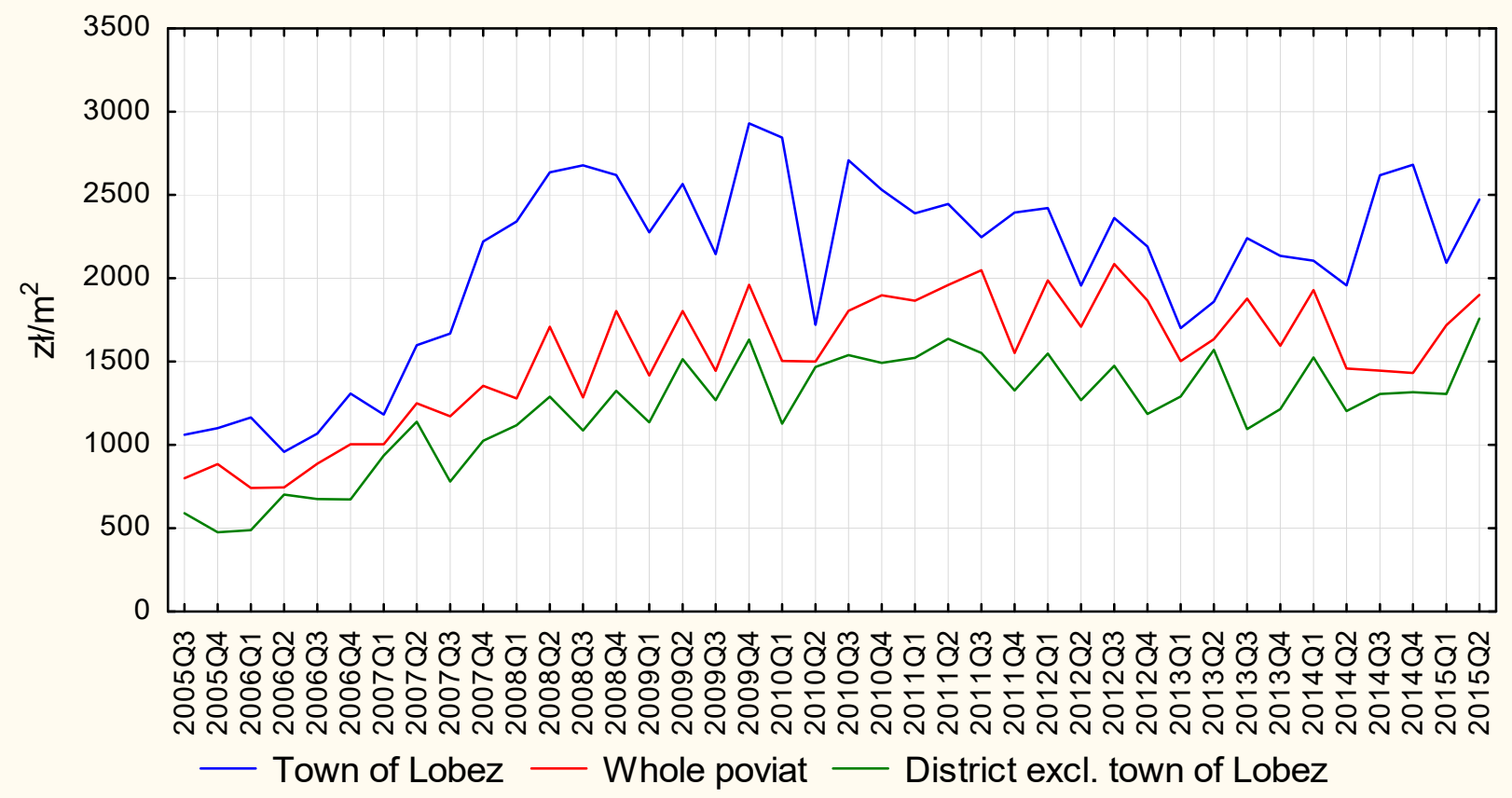

Fig. 2. Quarterly medians of residential property unit prices. Source: own study. 
The graph of quarterly medians is clearly less ragged (Figure 2). However, also in this case the fluctuations of prices from period to period are substantial enough to be unlikely to have resulted solely from market forces the district, the number of transactions in individual quarters ranges from 22 to 49 , which still turns out to be insufficient to eliminate the effects of the changing qualitative structure of the transaction sets in these quarters. The graph of semi-annual medians of unit prices is even less ragged (Figure 3). Here, we can say that the dramatic moves of these medians are rather rare. Nevertheless, from the point of view of the validity of the method chosen to determine price indices, even those rare episodes when the values do not follow general trends should be regarded as an effect which disqualifies this method. In this context, it seems to be highly improbable for sudden jumps in average prices from less than $2,000 \mathrm{zl} / \mathrm{m}^{2}$ to almost $2,700 \mathrm{zl} / \mathrm{m}^{2}$ to occur, as was the case in the district capital in the second half of 2014 compared to the first half of the same year. Another example is the drop in average prices from 1,830 zl/ $\mathrm{m}^{2}$ in the second half of 2013 to $1,430 \mathrm{zl} / \mathrm{m}^{2}$ in the second half of 2014 , i.e. by over $20 \%$ annually in the period that was commonly seen as a time of stability on the district market. Therefore, we can conclude that even the semi-annual medians of the unit prices are not reliable measures of average prices for the residential property market in Łobez.

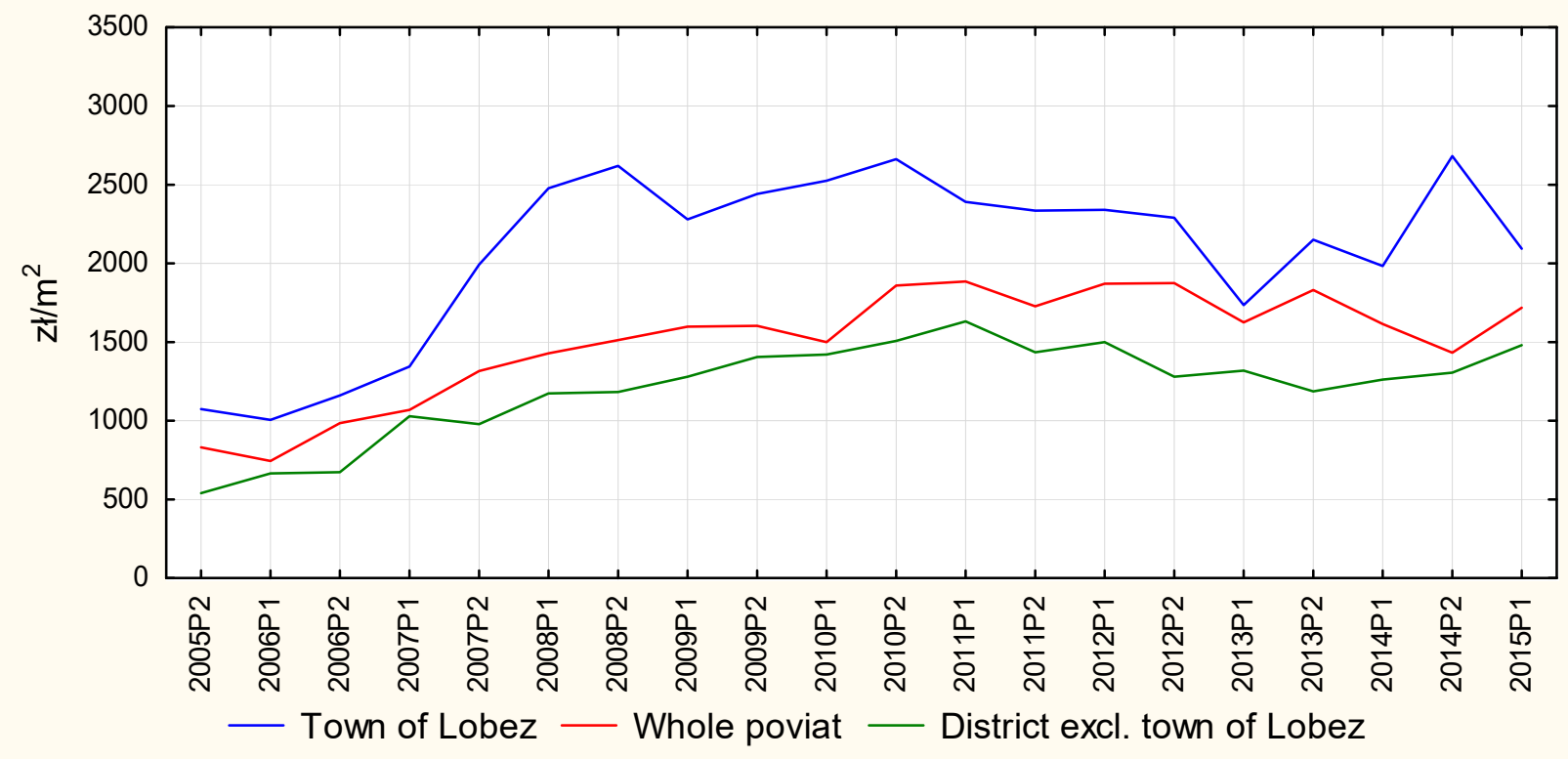

Fig. 3. Semi-annual medians of residential property unit prices. Source: own study.

Figure 4 shows the medians of unit prices determined on an annual basis. As seen below, such medians have relatively smooth graphs and seem to accurately represent the general price trends on the market. Unfortunately, their fundamental flaw is the fact that they cover relatively long, 12-month intervals, thus not reflecting, even in approximation, the changes on the market that can take place over a year. Thus, in comparison to the medians calculated for shorter intervals, annual medians should be regarded as strongly generalizing and imprecise. Yet, the very fact of obtaining smooth graphs of unit price medians proves that it is possible. The extended periods for which the average prices are computed lead to the smoothing of raggedness, i.e. to the elimination of the impact of random factors, particularly of the qualitative structure of residential properties marketed in those periods, on the average prices. This is, however, at the expense of the accuracy of results. 


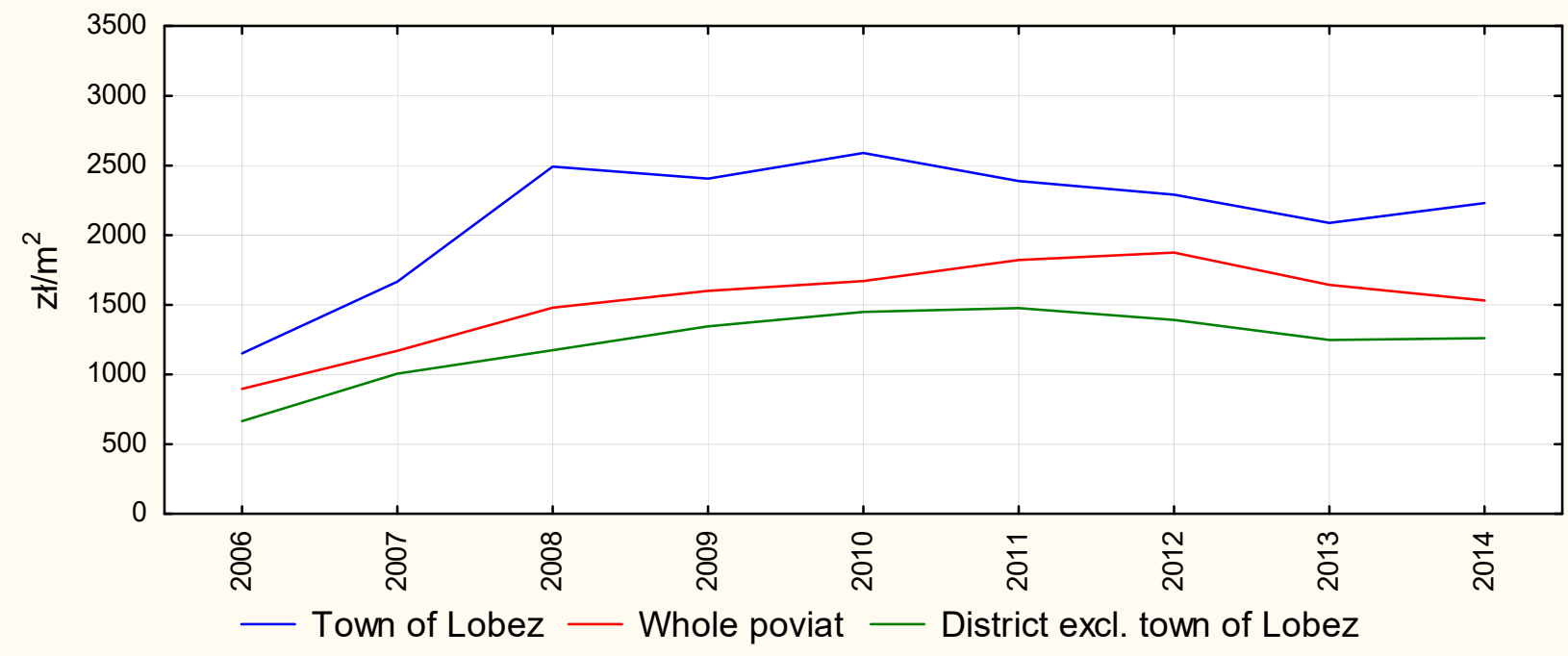

Fig. 4. Annual medians of residential property unit prices. Source: own study.

When searching for such a way of smoothing the series of unit price medians for the residential property market in the district of Łobez that would give reliable measures of unit prices on a more frequent than annual basis, the above-mentioned monthly, quarterly, semi-annual and (for comparison) annual series were filtered by means of the $4253 \mathrm{H}$ filter. The obtained values have been shown in Figures 5-8. For the sake of brevity, they are referred to as "smoothed medians" further in the paper. It is clear that the $4253 \mathrm{H}$ filter turned out to be ineffective in the case of monthly medians (Figure 5). The graphs of the smoothed monthly medians are ragged to such a degree that they should not be the basis for determining price indices. This is different in the case of the quarterly medians (Figure 6). The graphs of the smoothed quarterly medians present neither their sharp and frequent fluctuations, nor big jumps. Even though the fluctuations are gentle, they reflect main market trends. Therefore, it seems that, on the Łobez market, the smoothed quarterly medians of unit prices can be a basis for determining price indices. In the case of semi-annual and annual periods, the graphs of the smoothed medians are even gentler, so gentle that, similarly to the non-smoothed annual medians, they should be regarded as measures that are too generalizing and too imprecise (Figures 7 and 8). Yet, it is not to be ruled out that on other, particularly smaller local markets or in times of a bear market with significantly fewer transactions, only the smoothed semi-annual, or even annual, medians will give satisfactory results.

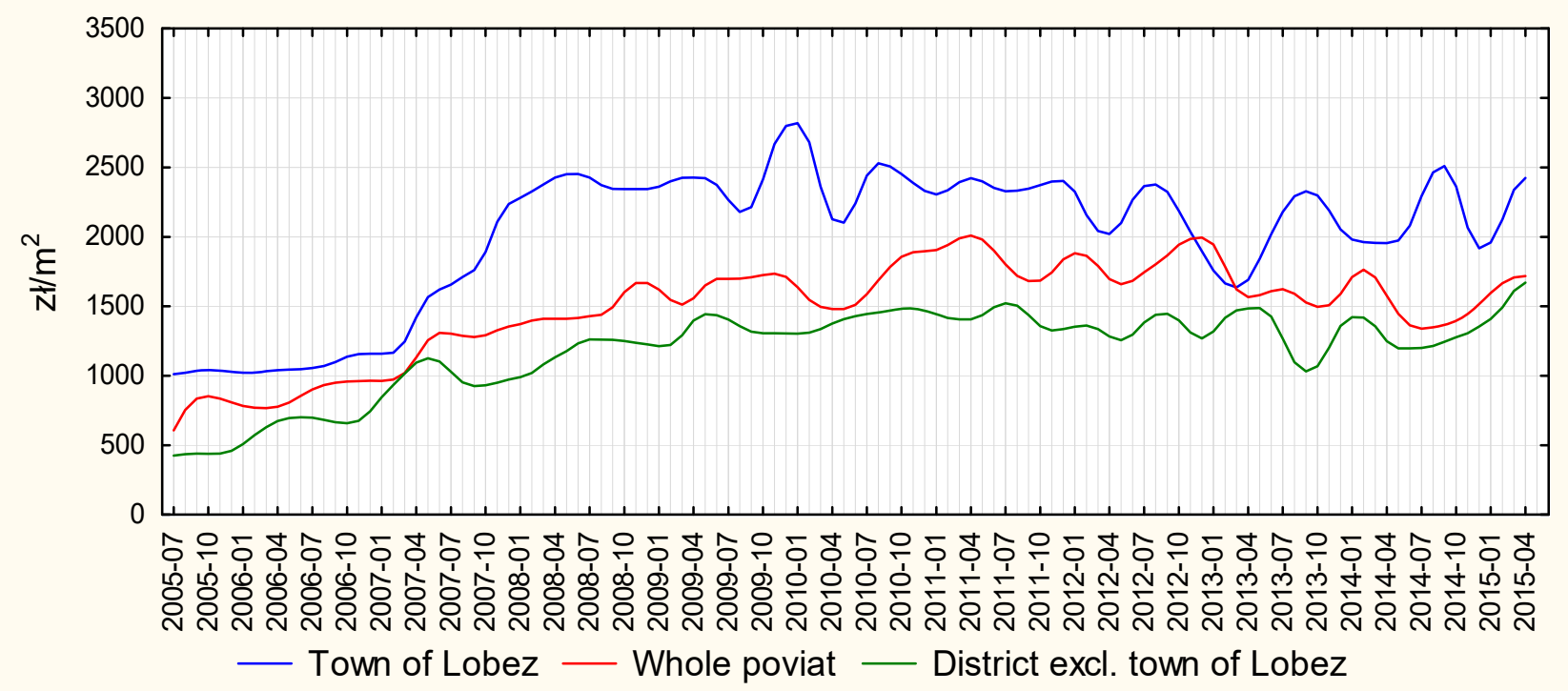


Fig. 5. Smoothed monthly medians of residential property unit prices. Source: own study.

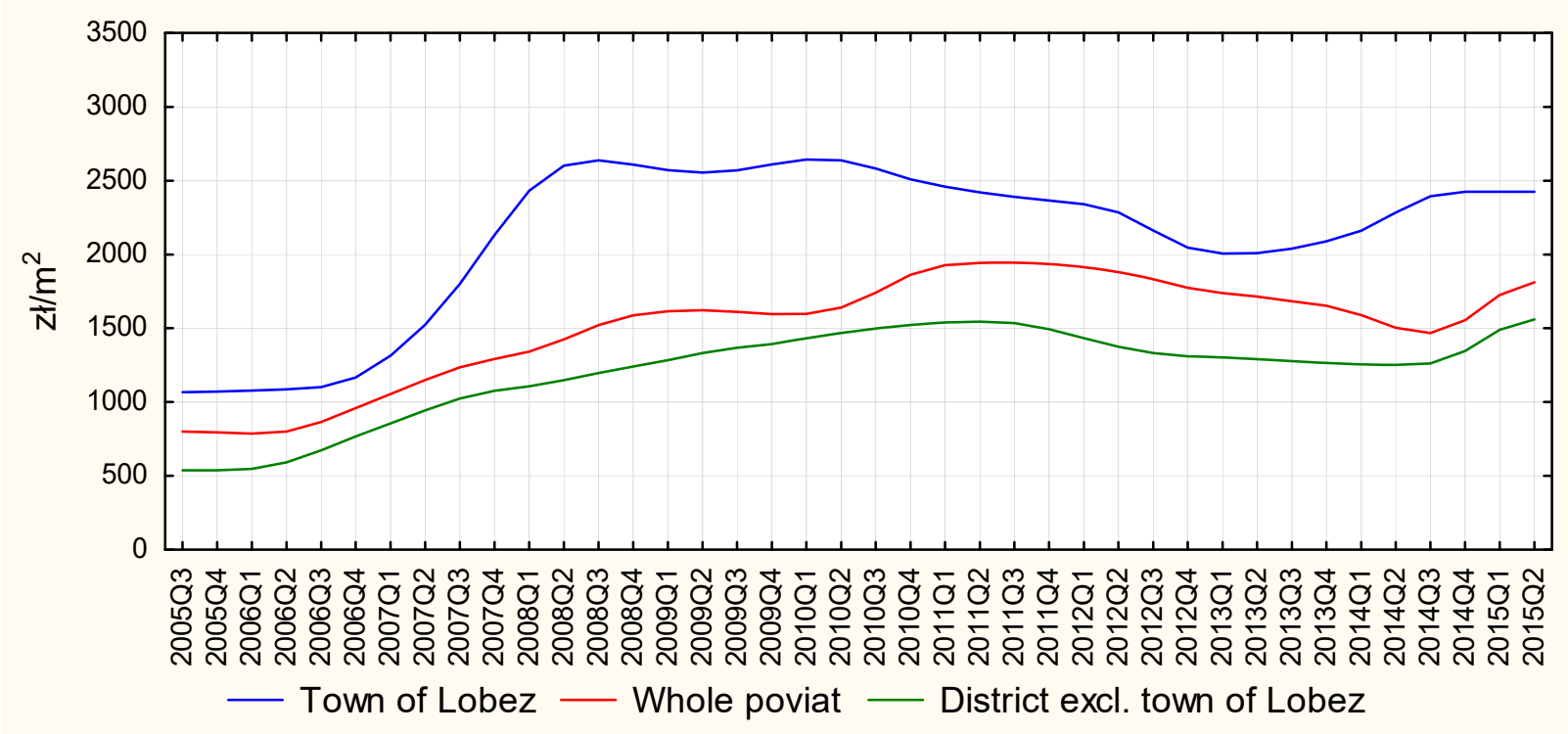

Fig. 6. Smoothed quarterly medians of residential property unit prices. Source: own study.

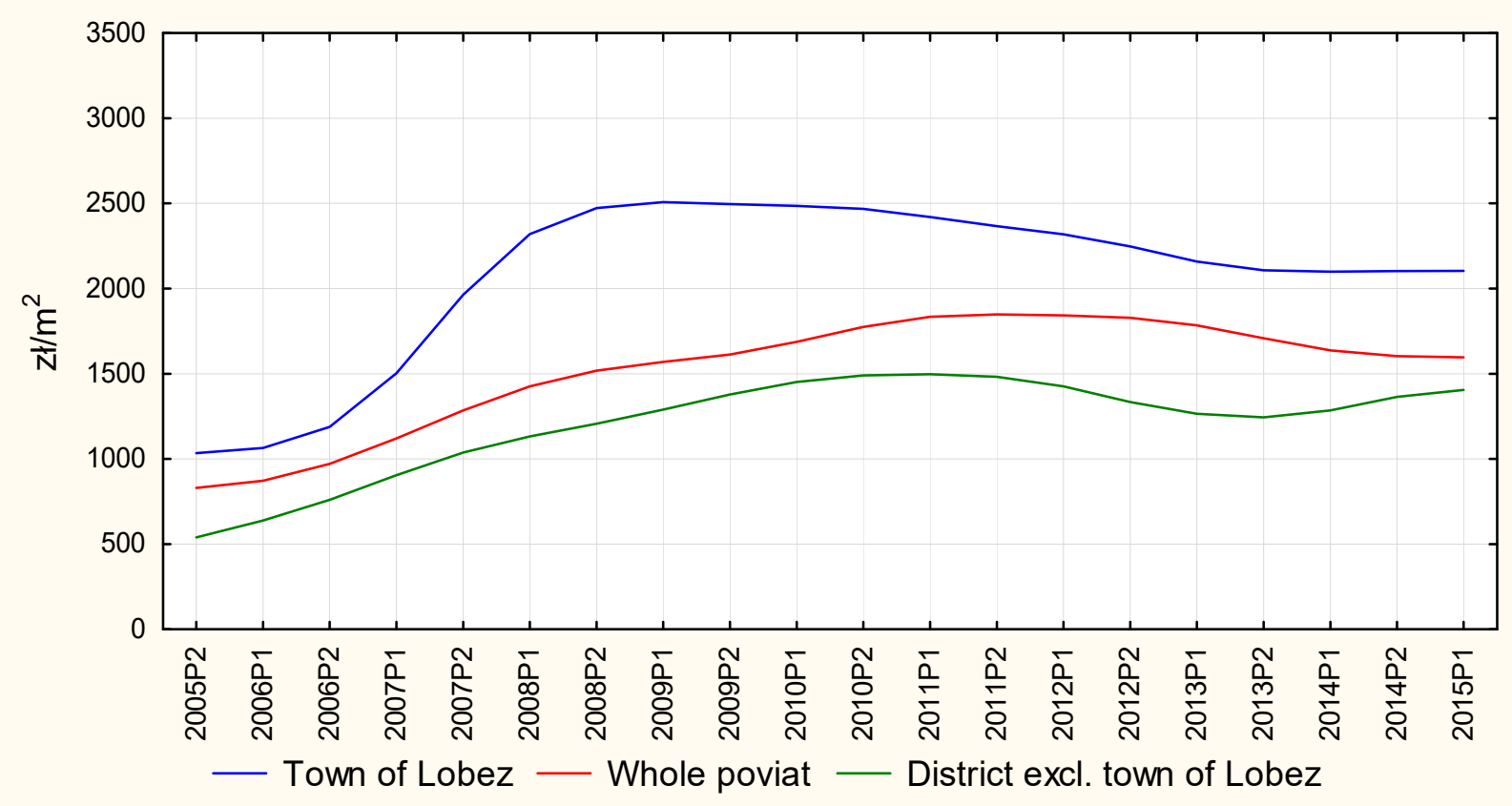

Fig. 7. Smoothed semi-annual medians of residential property unit prices. Source: own study. 


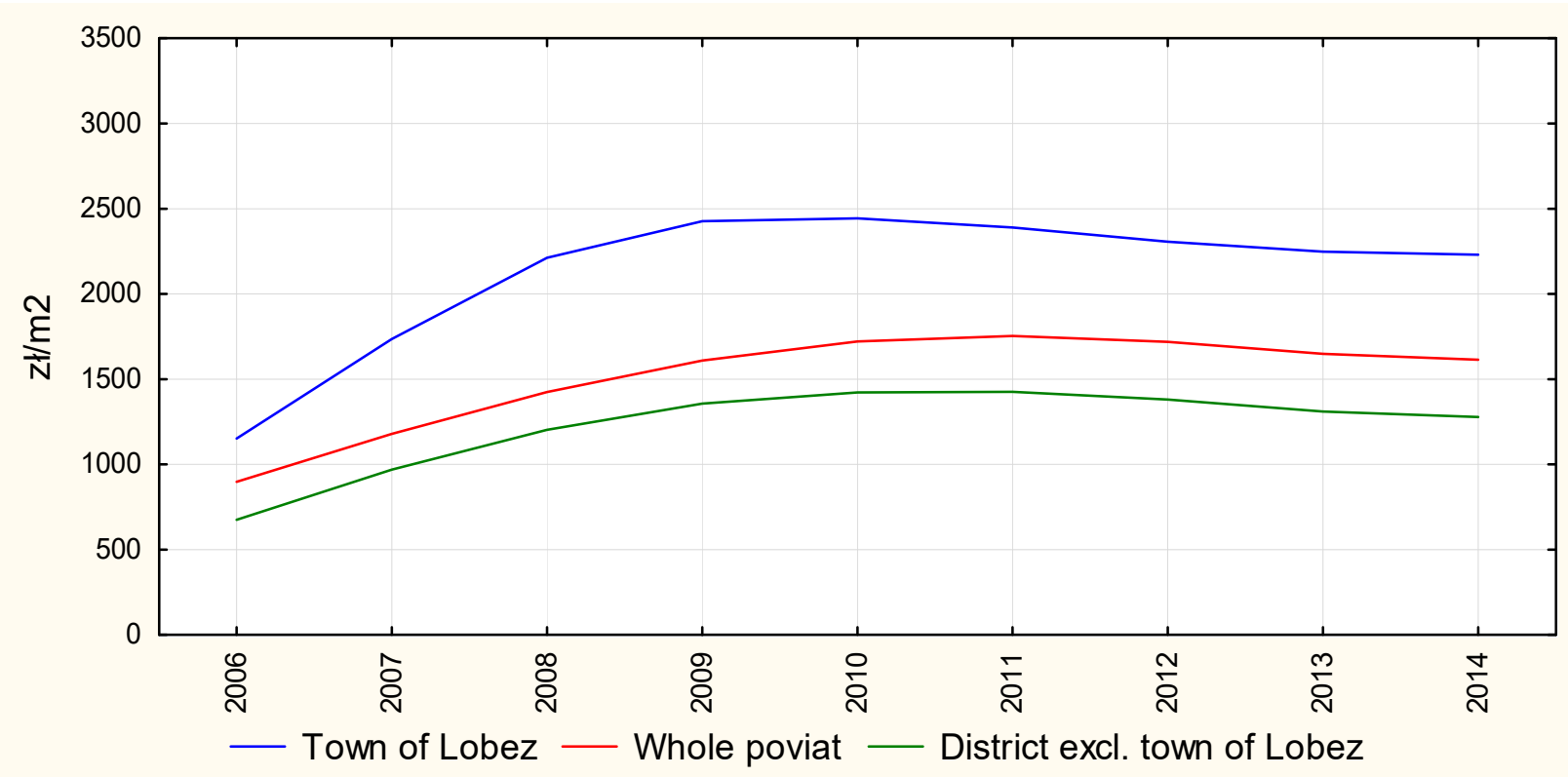

Fig. 8. Smoothed annual medians of residential property unit prices. Source: own study.

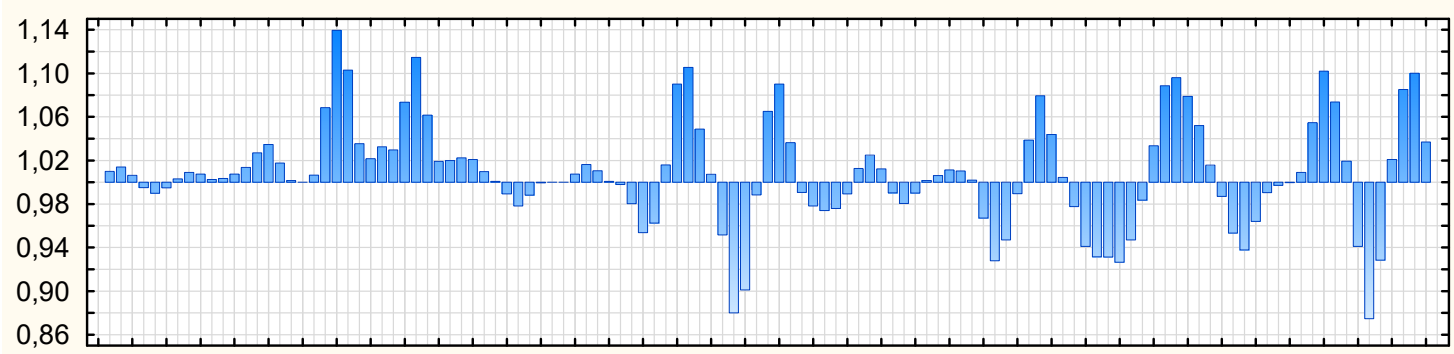

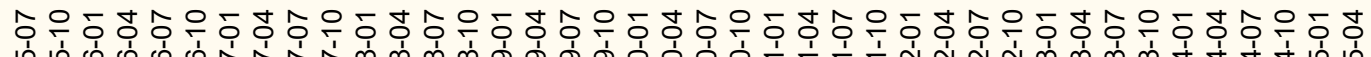

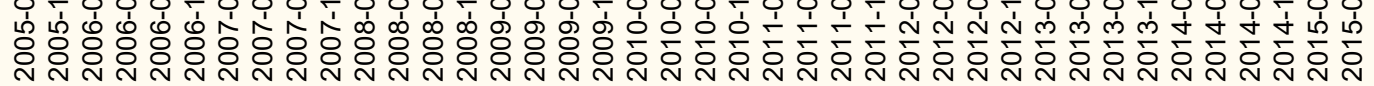

Fig. 9. Chain indices constructed from smoothed monthly medians of unit prices for the town of Łobez. Source: own study.

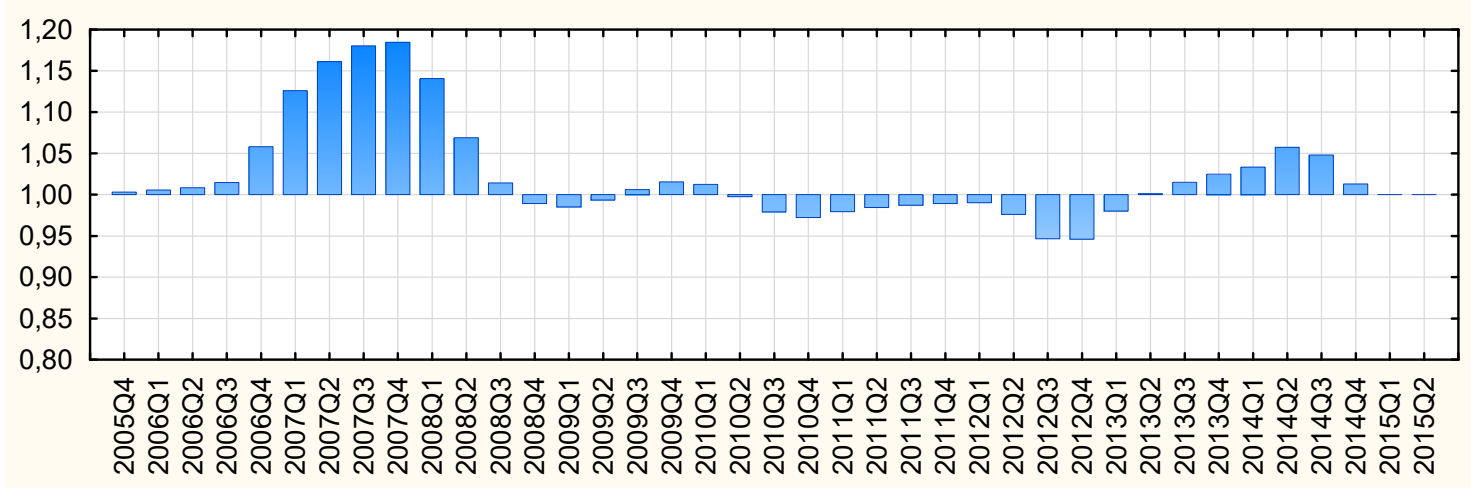

Fig. 10. Chain indices constructed from smoothed quarterly medians of unit prices for the town of Łobez Source: own study. 


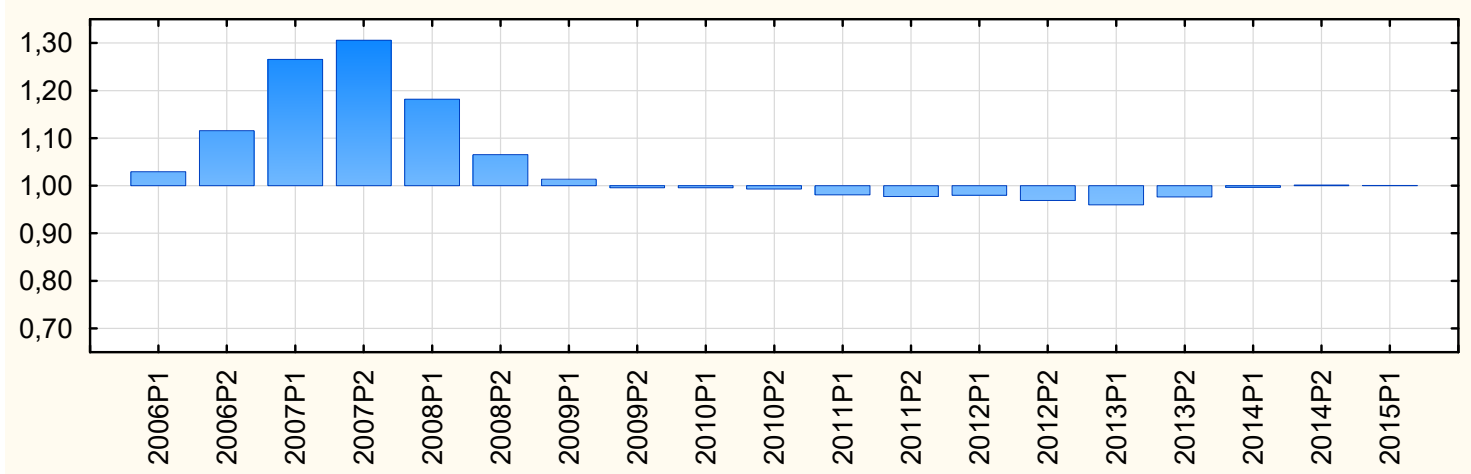

Fig. 11. Chain indices constructed from smoothed semi-annual medians of unit prices for the town of Łobez. Source: own study.

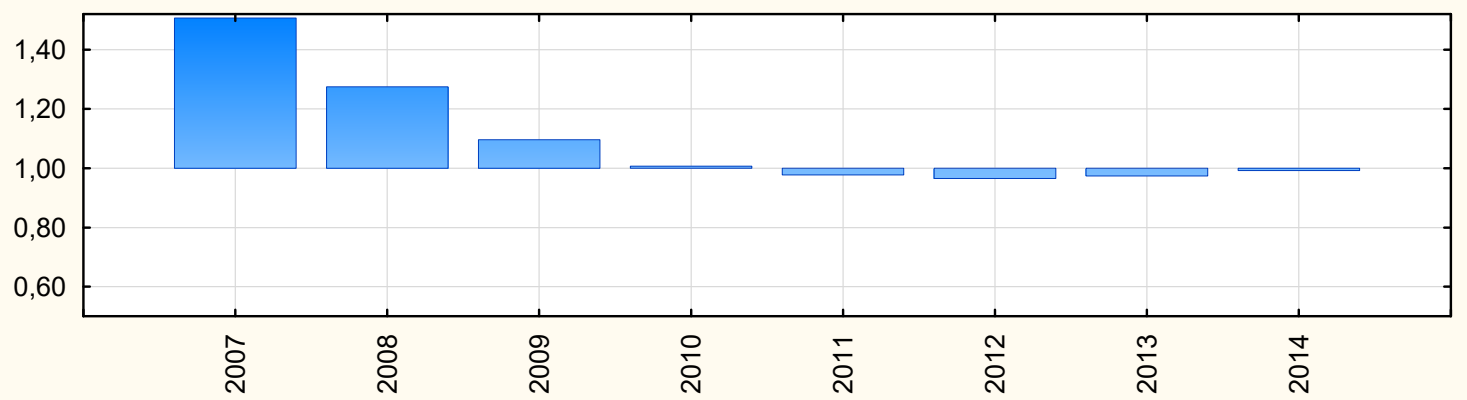

Fig. 12. Chain indices constructed from smoothed annual medians of unit prices for the town of Łobez. Source: own study.

Figures 9-12 show chain indices calculated from the monthly, quarterly, semi-annual and annual smoothed medians for the district capital. Although the conclusions above point to the ineffectiveness of monthly indices, they are presented, nevertheless, in order to show the consequences of determining the indices based on measures whose graphs are excessively ragged.

The informative value of thus determined indices lies both in reference to the length of the time periods for which they have been computed, and to the differences between their values in periods of various length. Therefore, when analyzing the indices derived from the smoothed monthly medians of unit prices in the town of Łobez, we can see that, in the period of dramatic price rise in Poland in 2006 - 2008, the local indices reached levels of 1.10-1.14, which should have translated to a price increase of $10-14 \%$ monthly. It is worth noting that high index values in that period alternated with much lower ones, sometimes falling below $1 \%$ monthly rise. Later, we can see short-term (no longer than a few months) upward and downward fluctuations occasionally exceeding $10 \%$ in plus or in minus over one month. Everyone who deals with real property market analysis knows that such short term price changes are highly unlikely and that they simply did not take place at all. The indices obtained in this manner should be considered unreliable, or even incorrect, and the method itself as inapplicable for the calculation of monthly indices. The situation is different with regard to indices calculated from the smoothed quarterly medians of unit prices. Here the index values for the periods, excluding three years between 2006 and 2008, indicate moderate changes in prices with clear and not infrequent upward and downward movements. Except for the aforementioned time of intense leaps in prices, their quarterly increases and decreases only sporadically exceeded $5 \%$, usually ranging from $0 \%$ to $3 \%$. Notably, when comparing the values of indices computed for monthly and quarterly periods, the former often revealed modules of higher percentage changes in prices; for example, the monthly indices for the first quarter of 2013 were 0.93, 0.95 and 0.98, respectively, which would mean that prices were falling from month to month - in January by $7 \%$, in February by $5 \%$ and in March by $2 \%$. Yet, the quarterly index for that period was 0.98 , which means a $2 \%$ fall throughout the whole first quarter of 2013 in comparison to the preceding quarter. Although, in theory, it is possible that the price fluctuations are stronger in a part of a period in time than over the entirety of this period, this is, first of all, highly unlikely in practice and, secondly, totally impossible that such things happen on a regular basis. Given the above, it seems justified to say that the monthly indices are unrealistic. From 
this point of view, the quarterly indices appear to be much more reliable. The comparison of semiannual and quarterly indices is not so unfavorable, but it often happens that the modules of percentage changes in prices are higher in the quarterly periods than in the semi-annual ones. For example, the quarterly indices for the second quarter of 2013 were 0.95 and 0.95 , respectively, which corresponds to a $5 \%$ quarterly price drop, while the semi-annual index for that period was 0.97 , which means that the prices fell by $3 \%$.

Similar conclusions can be drawn from the analysis of the obtained index values for the whole district of Łobez (Figures 13-16), as well as for the area of the district excluding the district capital (Figures 1720).

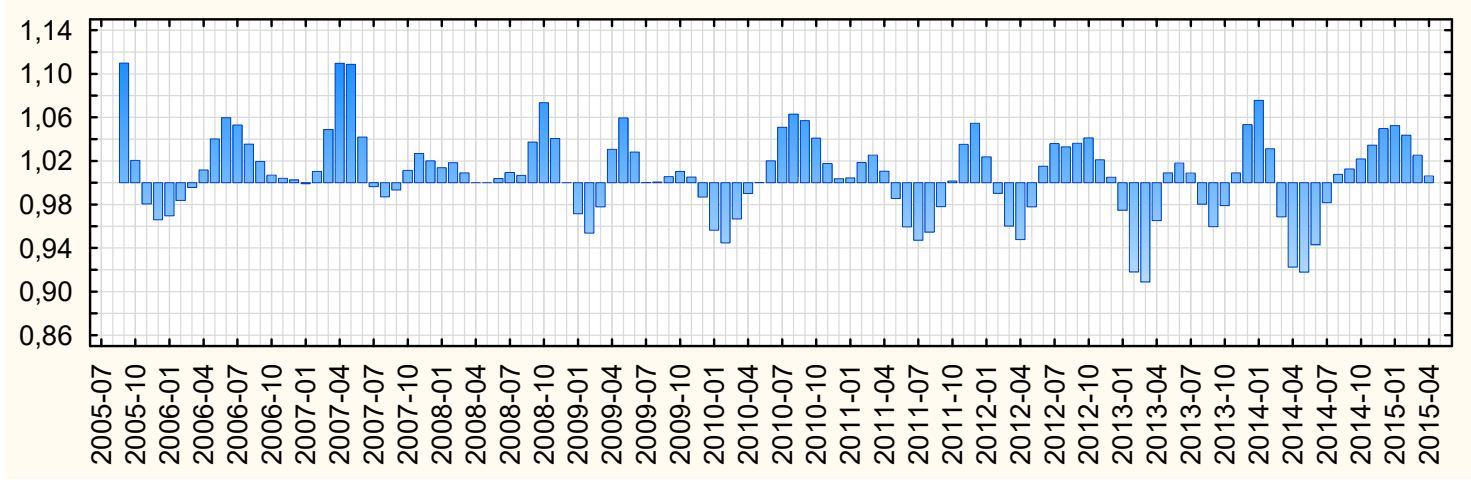

Fig. 13. Chain indices constructed from smoothed monthly medians of unit prices for the whole district of Łobez Source: own study.

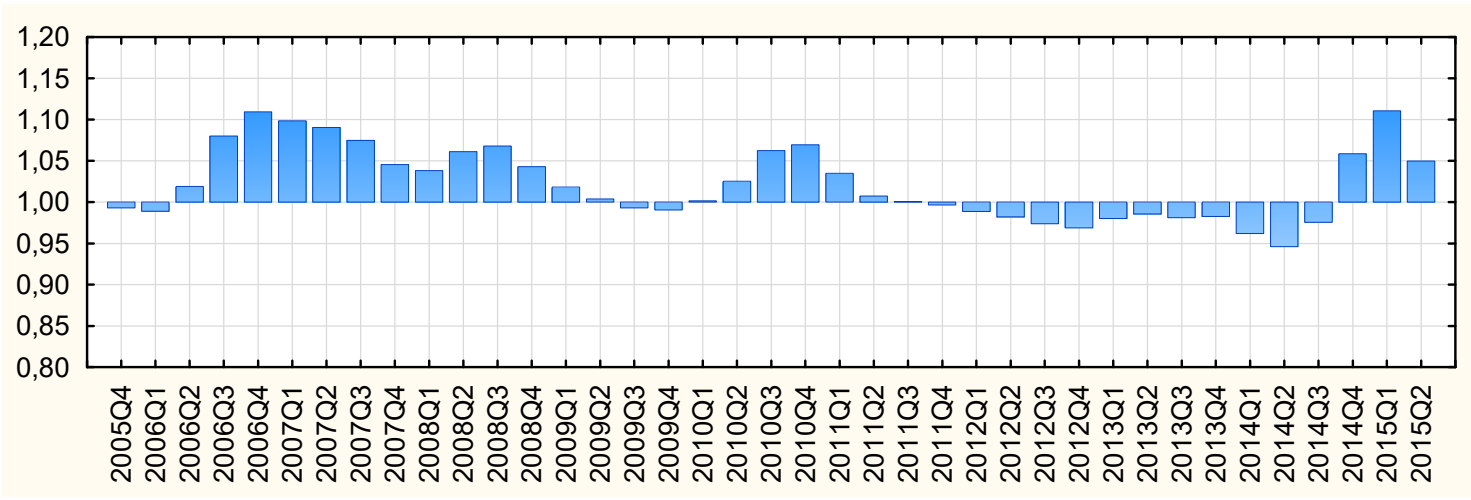

Fig. 14. Chain indices constructed from smoothed quarterly medians of unit prices for the whole district of Łobez. Source: own study.

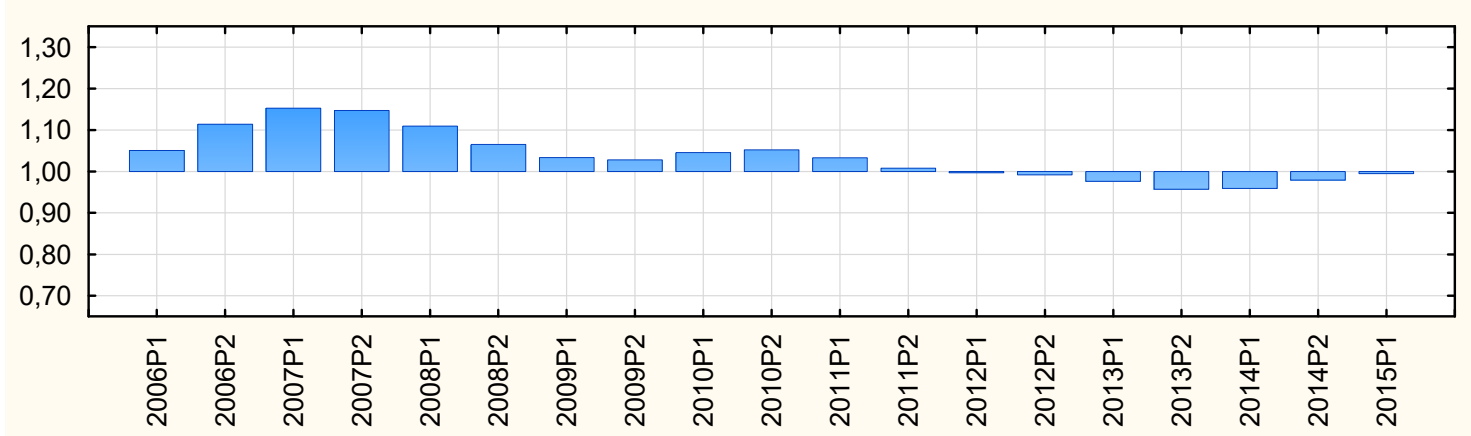

Fig. 15. Chain indices constructed from smoothed semi-annual medians of unit prices for the whole district of Łobez. Source: own study. 


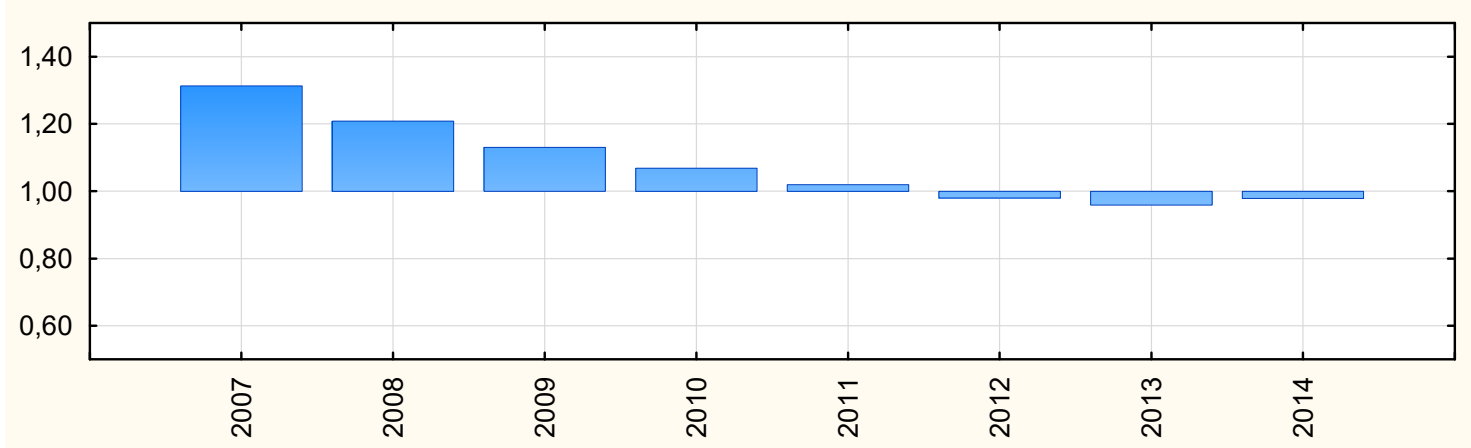

Fig. 16. Chain indices constructed from smoothed annual medians of unit prices for the whole district of Łobez. Source: own study.

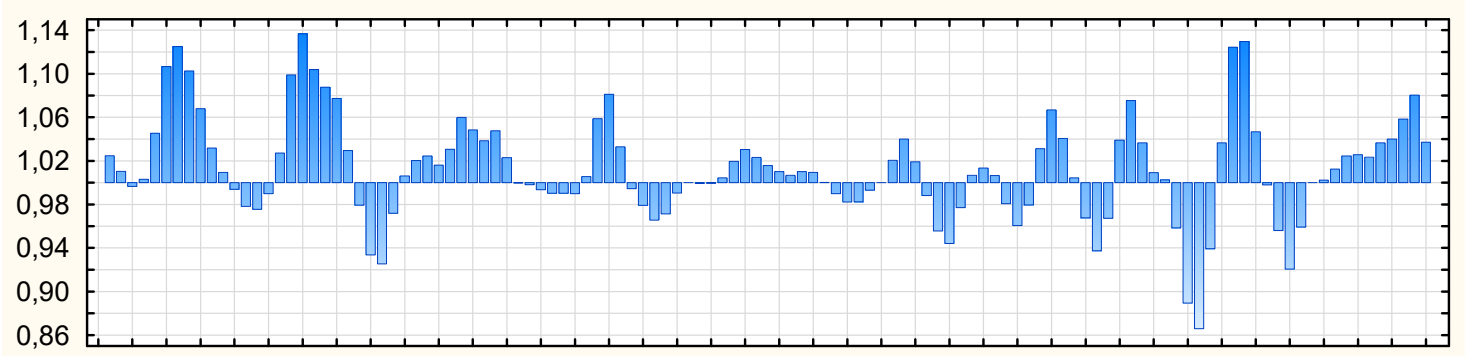

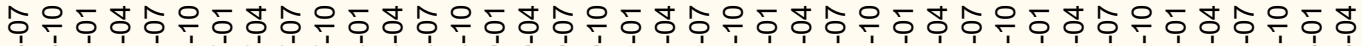

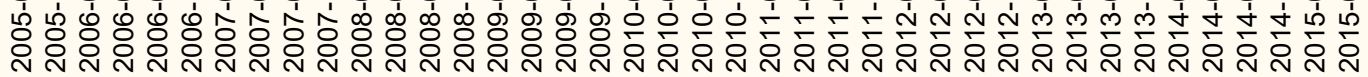

Fig. 17. Chain indices constructed from smoothed monthly medians of unit prices for the district of Łobez excluding the district capital. Source: own study.

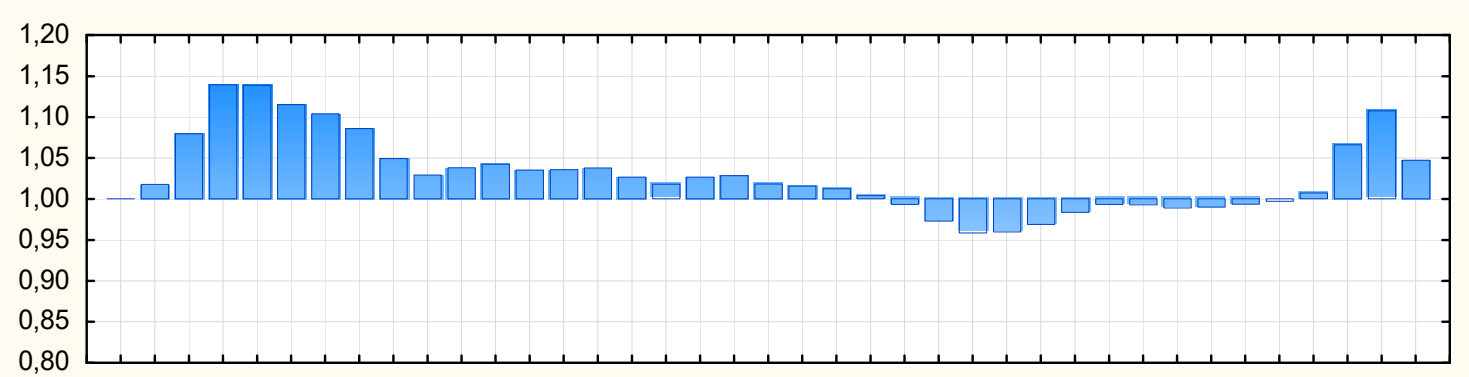

ఫ̛ఠ

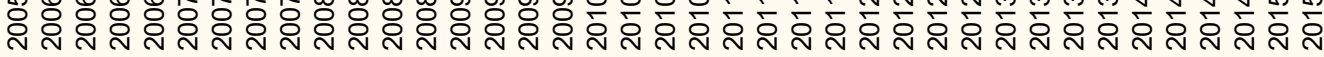

Fig. 18. Chain indices constructed from smoothed quarterly medians of unit prices for the district of Łobez excluding the district capital. Source: own study.

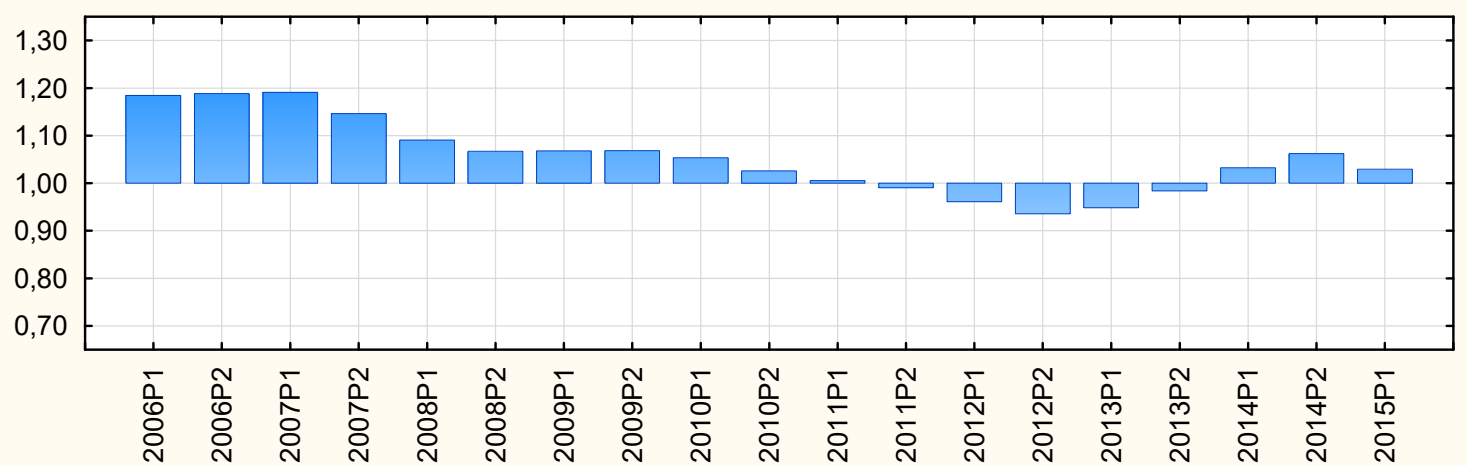

Fig. 19. Chain indices constructed from smoothed semi-annual medians of unit prices for the district of Łobez excluding the district capital. Source: own study. 


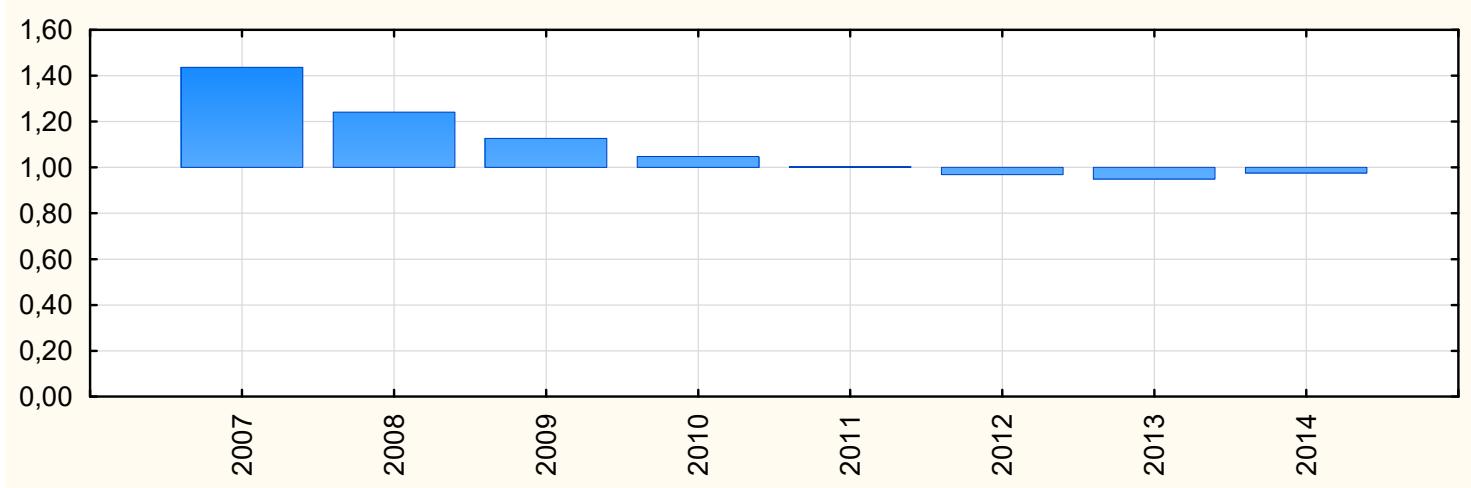

Fig. 20. Chain indices constructed from smoothed annual medians of unit prices for the district of Łobez excluding the district capital. Source: own study.

\section{Conclusions}

The fundamental problem that emerges when calculating real property price indices for small markets (and not only the small ones) by means of the proposed method is the assessment of the reliability of results, i.e. finding out how accurately they reflect actual average price movements and how sensitive they are to such random factors as the changeable qualitative structure of a marketed property in individual periods of time. Other factors that can blur the obtained results include delays in registering the concluded transactions (sometimes reaching six months) and the fact that the officially declared property price is not the one that was actually paid. The task of assessing the reliability of the obtained results is demanding as there is no standard which they could be compared to. So far, no formal methods of assessing the reliability of property price indices have been proposed. Therefore, such assessments usually have the character of expert opinions, and from such an expert's point of view, based on the above study, we can say that:

1. In the district of Łobez there are significant differences between the residential property unit prices recorded in the district capital town of Łobez and outside this town, which justifies treating these two territories as individual areas of research into real property prices and their dynamics,

2. The series of monthly, quarterly, semi-annual and annual medians of unit prices are ragged to such extent that they cannot be regarded as a basis for calculating property price indices. The series of annual medians of unit prices are smooth enough to be treated as the basis for computing property price indices, but such indices have limited informative value as the period they refer to is too long,

3. The $4253 \mathrm{H}$ filter significantly smooths the above-mentioned series. However, even having been smoothed, the series of monthly medians is not suitable for calculating property price indices. It seems that the smoothed series of quarterly, semi-annual and annual medians are better fitted to this purpose. In this sense, the combination of two smoothing methods, i.e. the prolongation of the periods for which the average unit prices are determined with simultaneous filtering should be considered the best method for calculating property price indices for the district of Łobez. Presumably, such a combination of methods will produce satisfactory results on other small real property markets. This thesis requires further verification by way of additional empirical studies.

What is more, further studies should focus on the development of formal and as much standardized methods as possible of selecting the best combination of the above-presented methods for smoothing the series of average unit prices so that the corresponding indices could best illustrate the real averaged price movements on a local market.

\section{References}

Baza Demografia (Demography Base). Stan i struktura ludności (State and Structure of the Population). Główny Urząd Statystyczny (Central Statistical Office).

Bezrobotni oraz stopa bezrobocia wg województw, podregionów i powiatów (stan w końcu sierpnia 2014 r). (The Unemployed and Unemployment Rate According to Provinces, Subregions and District (as of the End of August 2014)) [in Polish], 2014, Główny Urząd Statystyczny (Central Statistical Office). 
Bourassa S. C., Hoesli M., Sun, J., 2006, A Simple Alternative House Price Index Method, Journal of Housing Economics, 15 (1).

FRANCKE M.K., 2010, Repeat Sales Index for Thin Markets, The Journal of Real Estate Finance and Economics, Vol. 41, Issue 1.

GAMRACKI A., GAMRACKI J., 2009, Szacowanie emisji tlenków azotu (NOx) na podstawie danych eksploatacyjnych rzeczywistego obiektu przemysłowego (Assessing Nitrogen Oxide Emissions Based on Operational Data of an Actual Industrial Facility) [in Polish], Pomiary Automatyka Kontrola, nr 07 (Measurement Automatics Control, No. 7) , Gliwice.

GoOdhart, C., 2001, What Weight Should Be Given to Asset Prices in Measurement of Inflation? Economic Journal, Vol. 111.

GuO X., Zheng S., Geltner D., LiU H., 2014, A New Approach for Constructing Home Price Indices: The Pseudo Repeat Sales Model and its Application in China, Journal of Housing Economics, Vol. 25.

HILL R., 2011, Hedonic Price Indexes for Housing, OECD Statistics Directorate, Working Paper No. 36.

JANSEN S.J.T., DE VRIES P., COOLEN, H.C.C.H., LAMAIN C.J.M , BOELHOUWER P. J., 2008, Developing a House Price Index for The Netherlands: A Practical Application of Weighted Repeat Sales, Journal of Real Estate Finance and Economics, Vol. 37, Issue 2.

Kокот S., 2015a, Przyczynek do badań nad indeksami cen nieruchomości (Contribution to Studies on Real Estate Price Indices) [in Polish], Wiadomości Statystyczne nr 4, (Statistical News No. 4), Warszawa.

Kокот S., BAS M., 2013, Evaluation of the Applicability of Statistical Methods in Studies on Price Dynamics on the Real Estate Market, Real Estate Management and Valuation, Vol. 21, No. 1.

ŁASZEK J., WIDŁAK M., 2008, Badanie cen na rynku mieszkań prywatnych zamieszkatych przez właściciela z perspektywy banku centralnego (Studies of Prices on the Private Housing Market Inhabited by the Owner from the Perspective of the Central Bank) [in Polish], Bank i Kredyt (Bank and Credit), No. 39 (8), Narodowy Bank Polski (National Bank of Poland), Warszawa.

Nicholas T., ScherbinA A., 2013, Real Estate Prices During the Roaring Twenties and the Great Depression, Real Estate Economics, Vol. 41, Issue 2.

Obwieszczenie Prezesa Głównego Urzędu Statystycznego z dnia 14 października 2015 r. w sprawie wskaźników zmian cen dla lokali mieszkalnych w drugim kwartale 2015 r. z podziałem na województwa (Declaration of the President of the Central Statistical Office of 14 October 2015 on the issue of price change indicators for residential dwellings in the second quarter of 2015 with division into provinces) [in Polish].

Obwieszczenie Prezesa Głównego Urzędu Statystycznego z dnia 11 stycznia 2016 r. w sprawie wskaźników zmian cen dla lokali mieszkalnych w trzecim kwartale 2015 r. z podziałem na województwa (Declaration of the President of the Central Statistical Office of 11 January 2016 on the issue of price change indicators for residential dwellings in the third quarter of 2015 with division into provinces) [in Polish],

Powierzchnia $i$ ludność w przekroju terytorialnym w 2014 r. (Area and Population in Territorial Crossection in 2014) [in Polish], 2014, Główny Urząd Statystyczny (Central Statistical Office), Warszawa.

TOMCZYK E., WIDŁAK M., 2010, Konstrukcja i własności hedonicznego indeksu cen mieszkań dla Warszawy (Construction and Properties of Hedonic Housing Price Index for Warsaw) [in Polish], Bank i Kredyt (Bank and Credit), No. 41 (1), Narodowy Bank Polski (National Bank of Poland), Warsaw.

TrojaneK R., 2008, Wahania cen na rynku mieszkaniowym (Fluctuations on the Housing Market) [in Polish], Published by Akademia Ekonomiczna in Poznań (Economic Academy in Poznań).

Velleman P. F., 1980, Definition and Comparison of Robust Nonlinear Data Smoothing Algorithms, Journal of the American Statistical Association, Volume 75, Issue 371.

WIDŁAK M., 2010, Metody wyznaczania hedonicznych indeksów cen jako sposób kontroli zmian jakości dóbr. (Methods of Indicating Hedonic Price Indices as a Method of Controlling the Quality of Goods) [in Polish], Wiadomości Statystyczne (Statistical News), No. 9, Główny Urząd Statystyczny (Central Statistical Office), Warszawa.

Wood R., 2005, A Comparison of UK Residential Mouse Price Indices, BIS Paper No. 21.

Wycena nieruchomości (Real Estate Valuation), 2006, Hozer et al., Department of Econometrics and Statistics, University of Szczecin, Institute for Economic Analyses, Diagnoses and Forecasts, Szczecin. 